\title{
Feeding difficulties and eating disorders in pediatric patients with cancer
}

\author{
Erika Damasco-Ávila ${ }^{1}$, Liliana Velasco-Hidalgo ${ }^{1}$, Marta Zapata-Tarrés ${ }^{1}$, Rocío Cárdenas-Cardos ${ }^{1}$ and \\ Roberto Rivera-Luna ${ }^{2 *}$ \\ ${ }^{1}$ Departmento de Oncología Pediátrica; ${ }^{2}$ Subdirección de Hematología/Oncología Instituto Nacional de Pediatría, Mexico City, Mexico
}

\begin{abstract}
Background: Feeding difficulties and disorders are a common problem in the pediatric population, which involve a series of deficient behaviors about nutrition processes that can adversely affect psychomotor, psychosocial, and physical development of children. This study aimed to describe the frequency of feeding difficulties or disorders in pediatric patients with cancer. Methods: A prospective study which included 125 children from 1-19 years treated at the Department of Oncology of the Instituto Nacional de Pediatría, Mexico City, was conducted. The diagnosis of eating disorders and feeding difficüties was determined during the first $48 \mathrm{~h}$ since admission, and the age of the patient influenced the type of disorder and feeding difficulties. Results: Children older than 11 years presented more frequently an intense resistance of feeding because of discomfort pain (fear of feeding) than younger children (11.4 \pm 4.7 vs. $7.4 \pm 4.9, p \leq 0.001$ ). The most frequent alteration associated with malnutrition was loss of appetite (odds ratio [OR]: 8.8, confidence interval [Cl] 95\% 2.9-26.9, $p<0.001$ ), followed by fear of feeding (OR: 3.14, CI 95\% 1.24-7.9, $p=0.015$ ), and the organic causes showed the highest risk for malnutrition (OR: 3.1, Cl 95\% 0.98-9.7, $p=0.054$ ). Conclusions: Over $90 \%$ of the studied population demonstrated at least one eating disorder or feeding difficulty. The principal effect is inadequate nutritional intake due to limited appetite and fear of feeding, which can result in undernutrition. For this reason, the identification of alterations in nutrition processes should be part of the comprehensive assessment of cancer patients.
\end{abstract}

Key words: Feeding difficulties. Eating disorders. Children with cancer. Malnutrition.

\section{Trastornos y dificultades en la alimentación en pacientes pediátricos con cáncer}

\section{Resumen}

Introducción: Los trastornos y dificultades para la alimentación son problemas comunes en la edad pediátrica. Estas situaciones conllevan una serie de comportamientos inadecuados respecto de los procesos de nutrición que puêden afectar de manera adversa el desarrollo psicomotor, psicosocial y físico del niño. El objetivo de este trabajo fue describir la frecuencia de desórdenes y dificultades en la alimentación en niños con cáncer a través de un estudio prospectivo. Métodos: Se incluyeron 125 niños de 1 a 19 años de edad del Servicio de Oncología del Instituto Nacional de Pediätría, Ciudad de México. El diagnóstico de desorden y dificultad en la alimentación se determinó en las primeras 48 horass del ingreso. Resultados: Los niños mayores de 11 años presentan con mayor frecuencia resistencia a comer debido a dolor 
o malestar (miedo a comer) (11.4 44.7 años versus $7.4 \pm 4.9$ años; $p \leq 0.001)$. La alteración más frecuente asociada a malnutrición fue la disminución del apetito (razón de momios [RM]: 8.8; intervalo de confianza [IC] 95\%: 2.9-26.9; p<0:001), seguido del miedo a comer (RM: 3.14; IC 95\%: 1.24-7.9; $p=0.015$ ) y las causas con mayor riesgo de malnutrición füeron las orgánicas (RM: 3.1; IC 95\%: 0.98-9.7; p=0.054). Conclusiones: Se encontró que en más del $90 \%$ de esta poblaçión se presentó por lo menos un desorden alimentario o dificultad al alimentarse. El principal efecto es la ingesta nutriciónal inadecuada debida al apetito limitado y al miedo a alimentarse, lo que puede resultar en desnutrición. Por esta razón, la identificación de alteraciones en los procesos de nutrición deben ser parte de la valoración integral de los pacientesscon cáncer.

Palabras clave: Dificultad de alimentación. Trastornos de la alimentación. Niños con cáncer. Malnutrición.

\section{Introduction}

Feeding difficulties and disorders are common problems. In the pediatric population, these involve a sequence of poor behaviors about feeding processes, such as an inadequate composition of the diet, including quality, quantity, nutritional content, and type, which can adversely affect the psychomotor, psychosocial, and physical development of children (failure to thrive and macro- and micro-deficiencies).$^{1-7} \mathrm{~A}$ lack of nutrients, such as proteins, iron, zinc, and vitamin $A$, is the most common result of eating disorders. The developments of these eating alterations are usually associated with factors such as medical procedures or treatments, prolonged hospitalizations, and comorbidities. . $^{8,9}$ It is reported that approximately $25-45 \%$ of children with healthy development and up to $80 \%$ of children with developmental delay present difficulties or eating disorders, of which only $16-30 \%$ of the cases are due to organic problems. ${ }^{10-12}$

Eating disorders have been adequately addressed and discussed in adults and adolescents. In contrast, eating problems in childhood are an unclear topic. Determining the prevalence of feeding problems in children with cancer may be complicated since no universally accepted definition or classification system exists. ${ }^{3,13}$ However, there are three significant difficulties or disorders classified by Kerzner and Chatoor: limited appetite, selective intake, and fear of feeding. ${ }^{14,15}$ This classification facilitates the approach to the disorder and its possible underlying mechanisms and promotes an appropriate assessment and timely intervention. Unfortunately, a child with cancer may have more than one feeding problem, and the clinician will need to prioritize the intervention type.

This study aimed to describe the frequency of both feeding disorders and eating difficulties in pediatric patients with cancer undergoing treatment through a directed questionnaire for children or parents.

\section{Methods}

A prospective, transversal study was conducted from 2015 to 2016. Children from 1 to 19 years of age, dijagnosed with cancer, hospitalized, and treated at Department of Oncology, Instituto Nacional de Pediatría, Mexico City, during the time of the study were included. Patients who could read or parents were asked to answer the Identification and Management of Feeding Difficulties (IMFeD) questionnaire for children âfter an adequate explanation. This questionnaire has been designed to facilitate the identification of common feeding difficulties in children and consists of symptöms and statements that describe a feeding behavior int the child, first addressing issues of underlying organie disease and then brief descriptions of characteristics to identify other types of feeding difficulties. . $^{14,15}$

Nutritional assessment was determined according to the World Health Organization and UNICEF standarrds using weight, height, and age percentiles as parameters of growth to establish the actual nutrition status and to distinguish between acute and chronic malnutrition. ${ }^{16}$ We used length or standing height for ăge (height/age), weight for age and weight for length, or body mass index (BMI)/age percentiles according to age and gender. BMI/age was used to determine a present adequate nutritional status (eutrophic) or acute malnutrition or obese/overweight; for chronic malnutrition, the height/age parameter was used.

The screening of feeding disorders and difficulties was determined during the first $48 \mathrm{~h}$ after admission for chemotherapy treatment or surgery using the $\mathrm{M} M$ FeD questionnaire, which helps to determine qualitatively signs and symptoms that describe the behavior toward food. Finally, for eating disorders and feeding problem diagnosis, the original Kerzner and Chatoor classification was altered just by adding content to fit specific situations for oncological patients (Table 1 ). Patients whose parents signed the consent and patients above 12 years of age who signed an assent form 
Table 1. Classification of feeding disorders by Kerzner and Chatoor

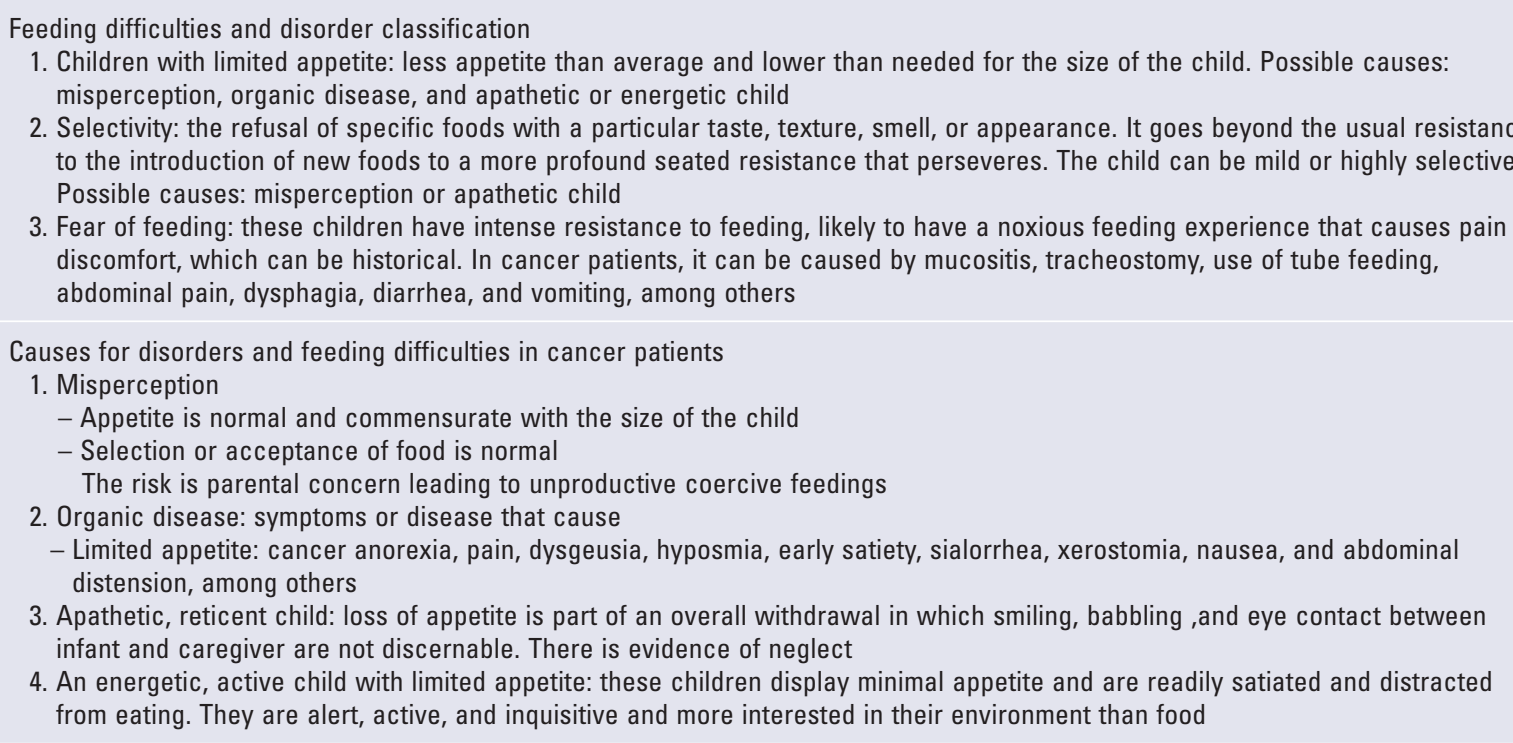
from eating. They are alert, active, and inquisitive and more interested in their environment than food

were included. ${ }^{17-19}$ The approval for the present research has been obtained from the Ethics Committee of the institution.

\section{Statistical analysis}

Continuous variables were compared with Student's t- or Mann-Whitney U-tests as appropriate and dichotomous variables with $\chi^{2}$.

A logistic regression analysis was performed to identify the variables with an independent association with the presence of malnutrition, including all variables with $p=0.05$ in the univariate analysis. Statistical program SPSS v.22.0 was used.

\section{Results}

Among the 125 individuals, $51.2 \%$ were female; the mean age was 8.7 years; 57 (45.6\%) had hematologic neoplasms and 68 (54.4\%) solid tumors. Other demographic characteristics and specific oncologic diagnosis of the population are shown in Table 2. Patients with an adequate nutrition status (eutrophic), according to their weight/height $(\mathrm{W} / \mathrm{H})$ or $\mathrm{BMl} /$ age, represent $41.6 \%$ of the total number of patients assessed. However, a high percentage of the population showed acute malnutrition (32.8\%) (W/H or BMl/age). Overweight/obesity (W/H or BMl/age) was observed in $25.6 \%$ and chronic malnutrition (H/age) in $23.2 \%$. Detailed nutritional data for the population are shown in Table 3.
Ninety-five patients $(76 \%)$ presented one feeding disorder; 19 (15.2\%) showed two disorders; and one-patient $(0.8 \%)$ showed three disorders. Only 10 patients (8\%) presented no feeding disorders. The disörder most commonly observed was limited appetite ( $\mathrm{n}=80$, $64 \%)$, followed by fear of feeding $(n=40,32 \%)$ and lectivity ( $n=16,13 \%)$.

The leading causes of feeding disorders and difficulties were identified as organic diseases $(n=100,80 \%)$, parent misperception $(n=8,6.4 \%)$, and apathetic of reticent child $(n=7,5.6 \%)$, and the cause in no case was an energetic child.

The most frequent symptoms in children with decreased appetite were as follows: pain ( $n=72,57.6 \%)$, early satiety $(n=40,32 \%)$, and dysgeusia $(n=29,23.2 \%)$. Moreover, the most common symptoms in patients with fear of feeding were diarrhea $(n=58,46.4 \%)$, vomiting $(n=27,21.6 \%)$, pain when chewing or swallowing due to mucositis $(n=22,17.6 \%)$, and abdominal distention $(n=19,15.2 \%)$. Children $>11.4$ years presented with a fear of feeding more frequently than younger children (11.4 \pm 4.7 vs. $7.4 \pm 4.9, p \leq 0.001$ ).

The feeding difficulty or eating disorder most frequently associated with malnutrition was loss of appetite (OR): 8.8, Cl 95\% 2.9-26.9, p < 0.001), followed by an intense resistance to feeding due to the discomfort/ pain associated with fear of feeding (OR: 3.14 , Cl $\overline{9} 5 \%$ 1.24-7.9, $p=0.015)$. The causes associated with the highest risk for malnutrition were organic (OR: 3.P. $\mathrm{Cl}$ $95 \% 0.98-9.7, p=0.054)$. In the multivariate analysis, the 
Table 2. Demographic and nutritional characteristics of the children

\begin{tabular}{|c|c|}
\hline Characteristics & $n=125$ \\
\hline $\begin{array}{l}\text { Gender } \\
\text { Female } \\
\text { Male }\end{array}$ & $\begin{array}{l}64(51.2 \%) \\
61(48.8 \%)\end{array}$ \\
\hline $\begin{array}{l}\text { Age (years) } \\
\text { Minimum and maximum } \\
\text { Mean }\end{array}$ & $\begin{array}{c}1-19 \\
8.7 \pm 5.1\end{array}$ \\
\hline $\begin{array}{l}\text { Diagnosis } \\
\text { Hematological malignancies } \\
\text { Leukemias } \\
\text { Lymphomas }\end{array}$ & $\begin{array}{c}57(45.6 \%) \\
47(37.6 \%) \\
10(8.0 \%)\end{array}$ \\
\hline Solid tumors & $68(54.4 \%)$ \\
\hline Sarcoma & $33(26.4 \%)$ \\
\hline Retinoblastoma & $8(6.4 \%)$ \\
\hline CNS tumors & $13(10.4 \%)$ \\
\hline Langerhans cell histiocytosis & $2(1.6 \%)$ \\
\hline Germinal tumors & $4(3.2 \%)$ \\
\hline Wilms tumor & $5(4.0 \%)$ \\
\hline Others & $3(2.4 \%)$ \\
\hline $\begin{array}{l}\text { Nutritional parameters } \\
\text { Weight (median [IOR]) } \\
\text { Height (median [IOR]) } \\
\text { Height/age (\%) } \\
\text { Weight/age }(\%) \\
\text { BMI/age (\%) }\end{array}$ & $\begin{array}{c}26(15.6-49.6) \\
135(100-153.5) \\
24(6.0-46) \\
32(8.0-66.5) \\
46(11-84.5)\end{array}$ \\
\hline $\begin{array}{l}\text { Nutritional status (W/H or BMI/age): } \\
\text { Eutrophic } \\
\text { Acute malnutrition } \\
\text { Overweight/obesity } \\
\text { Chronic malnutrition }\end{array}$ & $\begin{array}{l}52(41.3 \%) \\
41(32.8 \%) \\
32(25.6 \%) \\
29(23.2 \%)\end{array}$ \\
\hline
\end{tabular}

Results are expressed as $n(\%)$ unless otherwise is specified. W/H, weight /height; $\mathrm{BMI}$, body mass index; IQR, interquartile range.

variable which remained significant and was associated with malnutrition was the decreased appetite (OR: 5.2, $\mathrm{Cl} 95 \%$ 1.3-20.3, $\mathrm{p}=0.018)$. Concerning the prevalence of eating disorders and feeding difficulties, no differences between males and females nor between hematological and solid tumors were observed (Table 4).

\section{Discussion}

A correct feeding process is vital for the optimal development in children; however, inadequate nutritional intake due to limited appetite and fear of feeding is frequently observed and associated with malnutrition in oncology patients. Some patients do not lose significant weight. However, the imbalance between nutrimental
Table 3. Feeding difficulties and eating disorders prevalence

\begin{tabular}{|c|c|}
\hline Characteristics & \\
\hline $\begin{array}{l}\text { Feeding difficulty or eating disorder } \\
\text { One or more present } \\
\text { Not present } \\
\text { Limited appetite } \\
\text { Selectivity } \\
\text { Fear of feeding }\end{array}$ & $\begin{array}{c}\text { 穴 } \\
115(92 \%) \\
10(8 \%) \\
80(64 \%) \\
16(13 \%) \\
40(32 \%)\end{array}$ \\
\hline $\begin{array}{l}\text { Leading causes of feeding difficulty or eating } \\
\text { disorder } \\
\text { Organic disease } \\
\text { Parent misperception } \\
\text { Apathetic or reticent child } \\
\text { Energetic child }\end{array}$ & $\begin{array}{l}\frac{\frac{c}{n}}{\frac{n}{0}} \\
100(80 \%) \\
8(6.4 \%) \\
7(5.6 \%) \\
0 \%\end{array}$ \\
\hline $\begin{array}{l}\text { Organic disease as a cause of limited appetite } \\
\text { Pain or discomfort } \\
\text { Early satiety } \\
\text { Dysgeusia }\end{array}$ & $\begin{array}{l}72(56.7 \%) \\
40(32 \%) \\
29(23.2 \%)\end{array}$ \\
\hline $\begin{array}{l}\text { Organic disease as a cause of fear of feeding } \\
\text { Diarrhea } \\
\text { Vomiting } \\
\text { Pain when chewing or swallowing due to } \\
\text { mucositis } \\
\text { Abdominal distention }\end{array}$ & 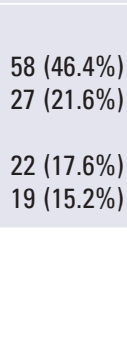 \\
\hline
\end{tabular}

requirement and intake may result in cumulative deficits of energy, protein, or micronutrients, which, in turn, may negatively affect growth, development, and outcomes as morbidity and mortality. ${ }^{18,19}$

Over $90 \%$ of the studied population demonstrated at least one eating disorder or feeding difficulty, which is a previously unreported data. Therefore, the importance of addressing these problems in children with cancer is emphasized. The most frequent disorders were fimited appetite, followed by fear of feeding both mainly associated with organic causes, although not closed to them. Some explanations for the presence of these alterations in children with cancer are factors such as dysfunctional hypothalamic signaling pathways and cytokine production associated with cancer that can lead to a dysregulation in appetite and food tolerance. 20 Furthermore, in some patients, chemotherapy, invasive medical/surgical procedures, and the use of specialized nutritional support as enteral or parenteral nutrition may cause significant signs and symptoms such as mücositis, dysphagia, abdominal distention, nausea, and̄vomiting, which are associated with pain when eating food acceptance and prolonged mealtimes ${ }^{21-26}$ contributing to the development of eating disorders or feeding difficulties.

Patients older than 11.4 years presented the highest frequency of fear of feeding possibly because 
Table 4. Feeding difficulties or eating disorders and malnutrition

\begin{tabular}{|c|c|}
\hline Characteristics & \\
\hline $\begin{array}{l}\text { Feeding difficulty or eating disorder } \\
\text { - Limited Appetite } \\
\text { - Selectivity } \\
\text { - Fear of feeding }\end{array}$ & $\begin{array}{c}\text { OR: } 8.8 \text { (Cl } 95 \% 2.9-26.9 ; \\
p<0.001) \\
N S \\
\text { OR: } 3.14 \text { (Cl } 95 \% 1.24-7.9 ; \\
p=0.015)\end{array}$ \\
\hline $\begin{array}{l}\text { Causes of feeding difficulty or } \\
\text { eating disorder } \\
\text { - Organic disease } \\
\text { - Parent misperception } \\
\text { - Apathetic or reticent child } \\
\text { - Energetic child }\end{array}$ & $\begin{array}{l}\text { OR: } 3.1 \text { (Cl } 95 \% 0.98-9.7 ; \\
\begin{aligned} & \mathrm{p}=0.054) \\
& \mathrm{NS} \\
& \mathrm{NS} \\
& \mathrm{NS}\end{aligned}\end{array}$ \\
\hline
\end{tabular}

In the multivariate analysis, the only variable which remained significant and was associated with malnutrition was the decreased appetite (OR: 5.2, $\mathrm{Cl} 95 \%$ 1.3-20.3, $\mathrm{p}=0.018$ ). NS, Not significant; $\mathrm{OR}$, odds ratio; $\mathrm{Cl}$, confidence interval.

they are more aware of the effects of the treatments on their food tolerance, and they associate symptoms such as diarrhea, mucositis, dysphagia, or dysgeusia with unpleasant and negative feelings toward food. This result points toward an area of opportunity in this age group, in which an appropriate intervention could be the preclusion or amelioration of such toxicity to prevent the development of this fear of feeding.

A third portion of the patients presented a state of acute malnutrition, similar to other reports, and a quarter of the population presented chronic malnutrition. It is important to remark that chronic malnutrition is defined by a lower than expected height and not mutually exclusive with the other categories (undernutrition or obesity/overweight). Furthermore, it occurred at a critical time of development and not necessarily associated with cancer. Among the eating disorders or feeding difficulties, only limited appetite remained significantly associated with malnutrition in the multivariate analysis. ${ }^{27}$

An interesting finding was that one-fourth of the children were obese or overweight. In general terms, obesity or overweight does not exclude the presence of any degree of malnutrition associated with involuntary weight loss. However, in this study, the nutritional status was classified taking into consideration the weight/height ratio to avoid memory bias or misinformation and avoid information which could lead to an underdiagnosis of malnutrition in this group of patients. It is important to mention that parental factors seem to explain only a minority of cases of eating disorders, ${ }^{28}$ which indicates that, in this population, the interventions should be primarily directed to the patients, their disease, and the prevention of the adverse effects from the antitumor treatments. Along with the process, the education of the parents regarding the feeding of their children is essential.

Assessment of infants, children, and adolescents with feeding disorders involves significantly more considerations than a clinical observation of feeding: What must be considered are the general health status, environment, parent-child interactions, and parental-concerns, in addition to the status of feeding. ${ }^{25,29,30}$ Dijagnosis must be early to provide timely treatment and obtain the best possible outcome. The high prevalence of malnutrition and feeding disorders in the pediatric population with cancer warrants interventional studies directed to correct these alterations. These interventions should be performed by a multidisciplinary tểam acquiesced by a physician, nutritionist, and psycho 0 cologist to achieve the most appropriate and consistent treatment that prevents or diminishes possible nutritional, psychomotor, and psychological alterations that may have a negative impact in the quality of life of the patient. The primary goal for every child is to receive adequate nutrition and hydration without health complications and stress to either the child or the caregiver; ${ }^{28,29}$ hence, the treatment should be tailored to the child and his family. Nutritional supplements or specialized nutritional support is useful to maintain or improve nutritional status, but they are temporary. ${ }^{3,31}$ Therefore, appropriate food and behavior education must be provided.

This study deals with a new topic in the nutritional and oncological field. Data were collected prospectively, and the sample is representative of pediatric cancers, which, in turn, can be a limitation due to the $\bar{h}$ terogeneity of the population.

Identification of feeding difficulties and disorders should be part of the comprehensive assessment of cancer patients. These disorders or difficulties of ding are a significant problem in the clinical field and have a high impact on the evolution of the patient, leading to a prolonged hospitalization, a higher degree of treatment-related toxicity, a reduced response to cancer treatment, an impaired quality of life, and a worse overall prognosis if the nutritional status results are affected. ${ }^{31-33}$

In conclusion, currently in Mexico, there is a high prevalence of obesity and overweight in the pediatric population with cancer, documented mainly among hematology malignancies. This problem has been detected since the diagnosis of numerous patients. However, it is developed in many others during the treatment for several 
reasons, such as the use of steroids, overcompensation by parents with food, sedentary lifestyle associated with hospitalizations and medical restrictions, and of course, a background of unhealthy habits. Despite the popular belief, a high BMI has been associated with worse overall and event-free survival in some groups, such as leukemia patients. In general, some complications observed such as impaired glucose intolerance and higher degrees of toxicity (i.e., diarrhea or vomiting) add to the increased risk of feeding problems due to high doses of chemotherapy as the total body surface increases. Consequently, nutrition and care during treatment should be monitored and a follow-up should be conducted periodically. It is important to mention this contrast because both populations present a high risk of presenting eating disorders or feeding problems.

The most prevalent findings in the current study were limited appetite and fear of feeding, which were not necessarily associated with tumor anorexia. On the contrary, these problems go beyond the obvious. Physical and psychological associations with pain, discomfort, environmental and food changes, and the presence of invading medical devices, among others, are strongly allied to the development of eating disorders and feeding problems. The risk becomes higher as the child grows older because he is more aware of the changes and the situation and is more in control of his behavior than an infant or toddler. However, more extended period studies with nutritional status follow-up and the development of these feeding difficulties and eating disorders will be necessary for a better understanding of why and when they begin to appear. These studies will allow formulating strategies for prevention and timely identification of those patients at high risk of nutritional alterations and optimal intervention and management of risk factors. Based on these findings, it is recommended that all oncologic units perform an analysis of these avoidable problems.

\section{Ethical disclosures}

Protection of human and animal subjects. The authors declare that no experiments were performed on humans or animals for this study.

Confidentiality of data. The authors declare that they have followed the protocols of their work center on the publication of patient data.

Right to privacy and informed consent. The authors have obtained the written informed consent of the patients or subjects mentioned in the article. The corresponding author is in possession of this document.

\section{Conflicts of interest}

The authors declare no conflicts of interest.

\section{Funding}

There was no external source of funding related to this research.

\section{References}

1. Arts-Rodas $D$, Benoit D. Feeding problems in infancy and early childhood: Identification and management. Paediatr Child Health. 1998;3:21-7.

2. Feeding difficulties in children-A guide for allied health professionals. Guideline. Ministry of Health, NSW website; 2016. Available from:www1. health.nsw.gov.au/pds/ActivePDSDocuments/GL2016_007.pdf.

3. Green RJ, Samy G, Miqdady MS, Salah M, Sleiman R, et al. How to improve eating behaviour during early childhood. Pediatr Gastroenterol Hepatol Nutr. 2015;18:1-9.

4. Benjasuwantep $B$, Chaithirayanon S, Eiamudomkan M. Feeding pröblems in healthy young children: prevalence, related factors and feeding practices. Pediatr Rep. 2013;15:38-42.

5. Bachmeyer M. Treatment of selective and inadequate food intake in children. Behav Anal Pract. 2009;2:43-50.

6. Piazza CC, Carroll-Hernandez TA. Assessment and treatment of pediatric feeding disorders. Montreal: Encyclopedia on Early Childhood Development Website; 2004. Available from: http://www.child-encyclopedia:com/ documents/Piazza-Carroll-Hernandez ANGxp.pdf.

7. Sim L, McAlpine D, Grothe K, Himes S, Cockerill R, Clark M. Identification and treatment of eating disorders in the primary care setting. Mayo Clin Proc. 2010;85:746-51.

8. Lask B, Fosson A, Rolfe U, Thomas S. Zinc deficiency and childhood-onset anorexia nervosa. J Clin Psychiatry. 1993:54:63-6.

9. Buchanan GR. The tragedy of iron deficiency during infancy and early childhood. J Pediatr. 1999;135:413-5.

10. Bryant-Waugh R, Markham L, Kreipe RE, Walsh BT. Feeding and eating disorders in childhood. Int J Eat Disord. 2010;43:98-111.

11. Babbitt RL, Hoch TA, Coe DA, Cataldo MF, Kelly KJ, Stackhouse $\bar{C}$, et al. Behavioral assessment and treatment of pediatric feeding disorders. J Dev Behav Pediatr. 1994;15:278-91.

12. Romano C. Current findings in pediatric non-organic feeding disōrders (nofeds): the gastroenterologist point of view. Ital J Pediatr. 2015;41:A61.

13. Benjasuwantep B. Successful treatment in a child with feeding problems and growth failure. J Med Assoc Thai. 2009;92:S60-4.

14. Kerzner B, Milano K, MacLean WC, Berall G, Stuart S, Chatoor' I. A practical approach to classifying and managing feeding difficulties. Pediatrics. 2015;135:344-53.

15. Kerzner B. Clinical investigation of feeding difficulties in young children: a practical approach. Clin Pediatr (Phila). 2009;48:960-5.

16. WHO Multicentre Growth Reference Study Group Geneva: World th Organization; 2006. WHO Child Growth Standards: length/height-forage, weight-for-age, weight-for-length, weight-for-height and body-mass index-for-age: methods and development. Available from: https://www. who.int/childgrowth/standards/Technical_report.pdf.

17. Garg P, Williams JA, Satyavrat V. A pilot study to assess the utility and perceived effectiveness of a tool for diagnosing feeding difficulties in children. Asia Pac Fam Med. 2015;14:7.

18. Arends J, Bachmann P, Baracos V, Barthelemy N, Bertz H, Bozzetti F et al. ESPEN guidelines on nutrition in cancer patients. Clin $>$ Nutr. 2017;36:11-48.

19. Becker P, Carney LN, Corkins MR, et al. Consensus statement of the-Academy of Nutrition and Dietetics/American Society for Parenteral and Enteral Nutrition: indicators recommended for the identification and documentation of pediatric malnutrition (undernutrition). Nutr Clin Pract. 2015;30:147-61.

20. Perboni $S$, Inui $A$. Anorexia in cancer: role of feeding-regulatory peptides. Phil Trans R Soc Lond B Biol Sci. 2006;361:1281-9.

21. Martyn PA, Hansen BC, Jen KL. The effects of parenteral nutrition on food intake and gastric motility. Nurs Res. 1984;33:336-42.

22. Chatoor I, Ganiban J, Harrison J, Hirsch R. Observation of feeding in the diagnosis of posttraumatic feeding disorder of infancy. J Am Acad Child Adolesc Psychiatry. 2001;40:595-602.

23. Stratton RJ, Elia M. The effects of enteral tube feeding and parenteral nutrition on appetite sensations and food intake in health and disease. Clin Nutr. 1999;18:63-70.

24. Reilly SM, Skuse DH, Wolke D, Stevenson J. Oral-motor dysfunction in children who fail to thrive: organic or non-organic? Dev Med Child Neurol. 1999;41:115-22. 
25. Segal I, Tirosh A, Sinai T, Alony S, Levi A, Korenfeld L, et al. Role reversal method for treatment of food refusal associated with infantile feeding disorders. J Pediatr Gastroenterol Nutr. 2014;58:739-42.

26. Ravelli AM, Milla PJ. Vomiting and gastroesophageal motor activity in children with disorders of the central nervous system. J Pediatr Gastroenterol Nutr. 1998;26:56-63.

27. Wright CM, Parkinson KN, Drewett RF. How does maternal and child feeding behavior relate to weight gain and failure to thrive? Data from a prospective birth cohort. Pediatrics. 2006;117:1262-9.

28. Brinksma A, Roodbol PF, Sulkers E, Hooimeijer HL, Sauer PJ, van Sonderen $\mathrm{E}$, et al. Weight and height in children newly diagnosed with cancer. Pediatr Blood Cancer. 2015;62:269-73.

29. Arvedson JC. Assessment of pediatric dysphagia and feeding disorders: clinical and instrumental approaches. Dev Disabil Res Rev. 2008:14:118-27.
30. Zangen T, Ciarla C, Zangen S, Di Lorenzo C, Flores AF, Cocjin J, et al. Gastrointestinal motility and sensory abnormalities may contribute to food refusal in medically fragile toddlers. J Pediatr Gastroenterol Nutr. 2003 37:287-93.

31. Dueñas Disputar $Y$, Murray Hurtado M, Rubio Morell B, Murjani Bharwani $\mathrm{H}$, Jiménez Sosa A. Trastornos de la conducta alimentaria en la edad pediátrica: una patología en auge. Nutr Hosp. 2015;32:2091-7.

32. Correia MI. Perman MI, Waitzberg DL. Hospital malnutrition in Latin America: a systematic review. Clin Nutr. 2017;36:958-67. doi: http://dx. doi.org/10.1016/j.clnu.2016.06.025.

33. Caccialanza R, Pedrazzoli P, Cereda E, Gavazzi C, Pinto C, PaccagneIla $A$, et al. Nutritional support in cancer patients: a position paper from the Italian Society of Medical Oncology (AIOM) and the Italian Society of Artificial Nutrition and Metabolism (SINPE). J Cancer. 2016;7:131e5. 